\title{
Comparative Constructions in Murui (Witotoan, Northwest Amazonia)
}

\author{
Katarzyna I. Wojtylak \\ Language and Culture Research Centre, James Cook University
}

This paper focuses on the forms and functions of various comparative constructions found in Murui, a Witotoan language of Northwest Amazonia (Colombia, Peru). It analyses different types of comparative construction, their forms, and semantics. This includes a set of special markers that express comparison, as well as those forms that are used in equative and similative constructions.

\section{Introduction}

Murui (also called Bue, Huitoto, or Witoto) is spoken by about 2000 people that inhabit the areas along the banks of the Cara-Paraná River in Colombia, and Ampiyacu and Napo Rivers in Peru (OIMA, 2008) (see Map 1). ${ }^{1}$

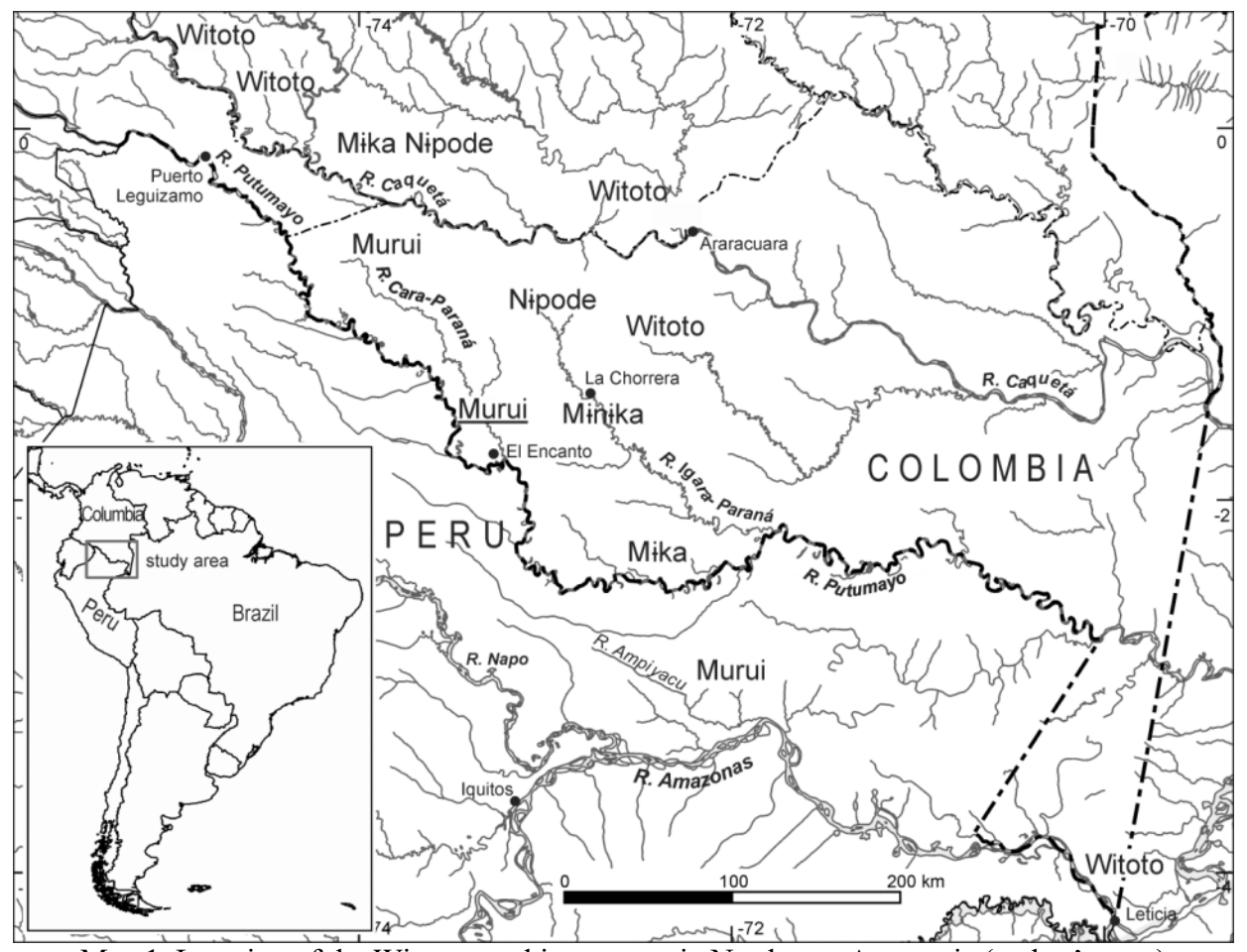

Map 1. Location of the Witoto-speaking groups in Northwest Amazonia (author's map)

\footnotetext{
${ }^{1}$ Information on Murui was obtained during an immersion fieldwork of 12 months on the Cara-Paraná River in Colombia, conducted between July 2013 and April 2016 to collect data for the reference grammar of Murui (Wojtylak 2017). The corpus was assembled from recordings of narrative texts (that deal with the group's everyday activities, mythology, past memories, etc.) and spontaneous language production (following methods of the Basic Linguistic Theory approach, Dixon 2010a-b, 2012). It includes over 700 pages of analysed and glossed texts, as well as over 1200 pages of field notes. Thanks to the Murui people for their patience and to the participants of the workshop 'Comparative and Superlative Constructions: Typology and Diachrony' (Amsterdam, 16-17 June 2015), as well as Alexandra Aikhenvald and Yvonne Treis for their helpful comments on the material.
} 
In the literature, the term 'Witoto' refers to a single language that belongs to the Witotoan language family (together with two other languages, Ocaina and Nonuya) (Echeverri, Fagua \& Wojtylak forthcoming). ${ }^{2}$ In fact, 'Witoto' is a collective umbrella term that encompasses four different ethnic groups that speak four mutually intelligible dialects: Murui, Mika, Minika, and Nipode (Wojtylak 2017). All these groups recognise their common ancestry but consider themselves to be separate social groups speaking different languages. In this paper, I refer to Murui as a language in the political sense although linguistically it is clearly one of the dialects. The Murui people (similarly to other Witotoan groups) have had intense contact with the western culture for over 100 years now, especially after the tragic consequences of the Rubber Boom period in the Amazon (Hardenburg 1912, Echeverri 1997, Pineda Camacho 2000). Fabre (2005) is a source of references on all the Witotoan languages.

The current sociolinguistic situation of the Murui people is characterised by a rapidly progressing language shift towards Spanish. The official records estimate the number of speakers of the Murui language at c. 2000, but, based on the author's fieldwork, in reality, this number does not exceed 1000 . The language is rapidly falling into disuse especially among younger speakers.

I start with a brief typological profile of the Murui language in section 2, focusing on word classes and their morphological and syntactic properties as relevant for the status and characteristics of comparative constructions. In section 3, I consider Murui comparative constructions focusing on their types and structure. This is followed by a discussion of Murui superlative strategies in section 4 and an analysis of the expression of equality and the similative $-z e$ in section 5 . The last section offers a brief summary.

\section{The Murui language}

Murui is nominative-accusative, agglutinating, and predominantly suffixing. Murui favours verbfinal constituent order (AOV, SV). Grammatical functions are expressed through case markers. Marking of core arguments is subject to differential case marking, that is related mainly to focus and topicality. Marking of oblique arguments (locative, ablative, instrumental, benefactive-causal, privative) is mandatory. There is only one cross-referencing position on the verb, the subject S/A. Murui has three open lexical word classes: nouns, verbs, and adjectives. There are ten semi-closed and closed word classes that include place and manner adverbs, time words, number words, quantifiers and intensifiers, pronouns, demonstratives, interrogative content words, connectives, adpositions, and interjections. A few adjectives (such as e.g. mare 'good') form a closed set of words (see Wojtylak 2017). ${ }^{3}$

\footnotetext{
${ }^{2}$ Some scholars consider the Witotoan languages to be related to the neighbouring Boran language family (see Aschmann's work (1993) on 'Proto-Witotoan'). Currently, Aschmann's account is treated as a working hypothesis. ${ }^{3}$ In this paper, the following abbreviations have been used: A subject of transitive verb, ABL ablative, AN animate, ANA anaphoric, ATT attributive, AUDIT auditory, CERT certainty, CLF classifier, COLL collective, DR 'derivational', DES desiderative, ENDEAR endearment (term), EMPH emphatic, E oblique core argument, EVENT event (nominalisation), F feminine, G general, GR group, GEN genitive, HAB habitual, IMMAT immature, IMP imperative, KIN kinship, lit. literally, LK linker, LOC locative, LOCAL locative oni, M masculine, NEG negation, NEUT neutral classifier, NMLZ nominalization, NP noun phrase, N.S/A topical non-subject, NSP non-specific, O object of transitive verb, P-MARK parameter marker, PERF peripheral (argument), pl plural, PRED predicate, PR 'pronominal' classifier, PRIV privative, Q question word, QUANT quantifier, RAPID rapid action, REM remote, $S$ subject of intransitive verb, sg singular, SMLF semelfactive, S-MARK standard marker, SP specific, Sp. Spanish loanword, UNCERT uncertainty, VCC verbless clause complement, VCS verbless copula subject, VS verbless subject, TH thematic affix.
} 
Verbs and nouns are distinctly different in their morphosyntactic features. For instance, nouns occur primarily as heads of NPs that can further function as heads of intransitive predicates (for first and second person), as in (1), or as arguments of verbless clauses (for third person), as in (2): ${ }^{4}$
(1) oo riño-di-kue $e_{\text {PRED }}$
2SG woman-CLF:DR.F-LK-1sg
'I am your woman.'
(2) bai-e jes $_{\mathrm{viko}}$
that-CLF:G dog
'That is a dog (lit. that - dog).'

Intransitive and transitive verbs are fully inflected for verbal morphology (tense, aspect, mood, evidentiality, directionality, as well as pronominal subject marking). (3) shows the transitive verbal root $f a$ - 'hit' followed by verbal morphology:

\begin{tabular}{|c|c|}
\hline $\begin{array}{l}\mathrm{e}_{\text {PRED }} \\
\text { sg }\end{array}$ & $\begin{array}{l}\text { nai-ñaiño } \\
\text { ANA.SP-CLF:PR.F }\end{array}$ \\
\hline
\end{tabular}

'Poor me (lit. I am poor). She hit me.'

Murui adjectives can function as predicates of intransitive clauses, as in (4), or can be used as arguments in verbless clauses, as in (5). The semantic difference between (4) and (5) is related to temporality. In (4), the attribution is 'temporal' (non-time-stable reference) - the place is dirty or ugly because someone did not clean it in the right way. In (5), it is 'timeless' (time-stable reference) - the fruit cannot revert to becoming 'not dirty, not ugly'. In both cases (4) and (5), naino 'that (place)' and jeaki 'dirty, ugly (fruit)' have to be referential, as indicated by the demonstrative biki 'this (fruit)'.

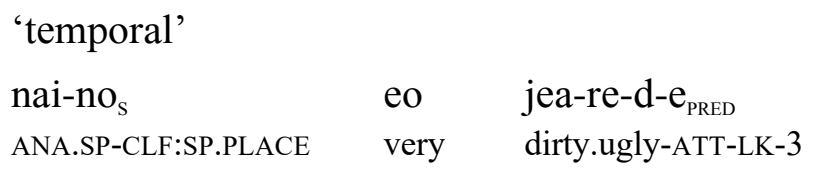

'That place is very dirty, ugly (lit. that place has a property of being dirty, ugly).'

(5) 'timeless'

$$
\begin{aligned}
& \text { bi-ki } \dot{\mathrm{v}}_{\mathrm{VCS}} \quad \text { jea-ki } \dot{\mathrm{v}}_{\mathrm{VCC}} \\
& \text { this-CLF:SMALL.ROUND dirty.ugly-CLF:ROUND }
\end{aligned}
$$

'This fruit is dirty, ugly (lit. this fruit - dirty, ugly (fruit)).'

Murui verbs, adjectives, and nouns are different in their morphosyntactic attributes from other word classes, and in the structural positions available for them. For instance, adjectives cannot take many of the aspectual markers such as the semelfactive -no; verbs cannot co-occur with the inchoative 'become' -nai, -tai, and -rui markers; neither verbs nor adjectives can be marked with

${ }^{4}$ For phonetic symbols, the following conventions are used throughout this paper: $<\mathrm{f}>$ represents the voiceless bilabial fricative, $<\mathrm{v}>$ is the voiced bilabial fricative, $<\mathrm{z}>$ is the voiceless dental fricative, $<\mathrm{r}>$ is the flap, $<\mathrm{ch}>$ and $<\mathrm{y}>$ are the voiceless and voiced lamino-palatal affricates, and $<j>$ is the voiceless glottal fricative. 
nominal morphology (unless they take classifiers) (see Wojtylak 2018). The syntactic properties of Murui open word classes are given in Table 1 below.

\begin{tabular}{c|c|c|c}
\hline Parameters & Verbs & Adjectives & Nouns \\
\hline $\begin{array}{c}\text { head of intransitive } \\
\text { predicate }\end{array}$ & yes & yes & yes \\
\hline $\begin{array}{c}\text { head of transitive } \\
\text { predicate }\end{array}$ & yes & no & no \\
\hline head of NP & $\begin{array}{c}\text { yes (when occur } \\
\text { with classifiers) }\end{array}$ & $\begin{array}{c}\text { yes (when occur } \\
\text { with classifiers) }\end{array}$ & yes \\
\hline modifier in NP & no & yes & yes \\
\hline modifier to verbs & no & $\begin{array}{c}\text { yes (when occur } \\
\text { with attributive } \\
\text { markers) }\end{array}$ & no \\
\hline
\end{tabular}

Table 1. Murui open word classes and their functional slots

Similar to other neighbouring languages spoken in the vicinity of the Vaupés linguistic area to the north, Murui has a large multiple classifier system with quite complex derivational functions. ${ }^{5}$ Murui classifiers are suffixes that can be defined as sets of morphemes which are used in various morphosyntactic contexts forming nouns (Wojtylak 2016). These contexts include: a) nouns (free and bound roots), b) verbs, c) adjectives, d) number words, e) pronouns, f) demonstratives, g) interrogative content words, and h) quantifiers. An example of the functions c) and f) is presented in (6):
bi-foro ${ }_{\mathrm{VCS}}$
aiyo-foro $_{\mathrm{VCC}}$
ebi-foro ${ }_{\mathrm{vCC}}$
this-CLF:FEATHER.SHAPED
big-CLF:FEATHER.SHAPED
nice-CLF:FEATHER.SHAPED

'This palm leaf is big and beautiful (lit. this (feather shaped) - big (feather shaped) - nice (feather shaped)).'

Murui predicates are typically marked for third person with the pronominal S/A subject marker $-e$. Optionally, for highly animate referents, the nonsingular number of S/A arguments can be marked on the predicates by the bound pronominal subject marker -maki. Similarly, nouns can remain unmarked; plural, kinship plural, and collective number marking is optional. Although the nonsingularity of nouns is usually determined by context, number marking tends to be expressed when the nouns are pragmatically salient and/or have human referents (see Smith-Stark 1974). In (7), jito 'son' could refer to any number of sons:

$\begin{array}{llll}\text { (7) } \text { jito }_{\mathrm{S}} & \text { uri } & \text { i-t- } \mathrm{e}_{\text {PRED }} & \text { anane-ko-mo } \mathrm{MPRF}_{\text {PER }} \\ \text { son } & \text { calm } & \text { exist-LK-3 } & \text { maloca-CLF:COVER-LOC }\end{array}$

'Son(s) is (are) quiet in the communal roundhouse (Sp. maloca).'

Unlike other classifier systems in Amazonia (Aikhenvald 2003), Murui classifiers do not mark full agreement within an NP. Modifying elements, such as demonstratives, do not agree with the head

\footnotetext{
${ }^{5}$ Multiple classifier systems are an areal phenomenon characteristic to languages located in the vicinity of the Vaupés linguistic area, including Tariana, Baniwa, and Palikur (Arawak), Bora and Miraña (Boran), Yagua (the only surviving language of the Peba-Yagua family), and East Tucanoan languages (see e.g. Aikhenvald 2003, 2012, Petersen de Piñeros 2007, Ramirez 1997, Seifart 2007, Seifart and Payne 2007).
} 
noun in classifiers, and are always marked with the general classifier $-e$ (or -je) regardless of their semantics or number, e.g. bie riño 'this woman', bie jofo 'this house'. Agreement in Murui is indicative of the distinction between an NP and a clause: classifiers obligatorily occur as agreement markers only in equational clauses. Example (8) is a full sentence in Murui-it consists of a verbless clause which contains two juxtaposed NPs, and the classifiers are 'matched'. (8b) is an NP.

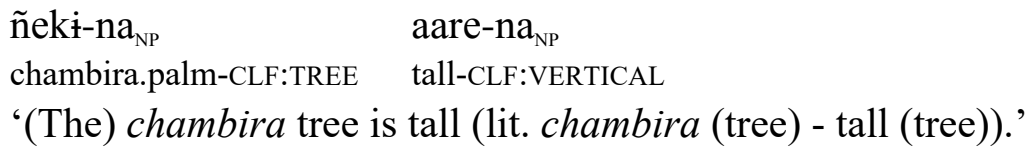

(8b) $\quad[\text { bai-e } \quad \text { ñeki-na }]_{\mathrm{NP}}$ that-CLF:G tall-CLF:TREE 'that chambira (tree)'

Murui has no copula verb. There is a verb $i(t e)$ which translates as 'exist, be, live'. It behaves as any other intransitive verb in the language, and can be used to express possession. In (9), $i(t e)$ marks a type of ownership:

$$
\begin{aligned}
& \text { kue-mo } o_{\text {PERF }} \quad \text { uru-iai } \dot{a}_{S} \quad i-t-e_{\text {PRED }} \\
& \text { 1sg-LOC child-CLF:G.PL exist-LK-3 }
\end{aligned}
$$

Murui has a classifier $-f e$ meaning 'side', as in (10), that can also function as a linker of sorts followed by classifiers, as in (11). Murui number words also take $-f e$, as in (12):

(10) ana-fe below-CLF:SIDE 'downside, lowland'

(11) foo-fe-be-ji inside-CLF:SIDE-CLF:LEAF-CLF:WATERY

'on the inside of the water'

(12) na-ga-fe-be-kuiro ANA.SP-QUANT-CLF:SIDE-CLF:LEAF-CLF:PEEL 'ten (lit. all sides of leaf peels)'

Murui has no morphological derivations such as augmentative or diminutive. Such concepts are expressed in the language by means of classifiers, such as $-k \dot{t}$ 'round (smaller)' vs. -gi 'oval (bigger)'. 


\section{Murui Comparative Constructions}

Murui has a number of dedicated comparative constructions that are characterised by the occurrence of special forms of STANDARD MARKERS, as well as by their specific structure. All Murui comparative constructions will commonly include the structural elements outlined in Table $2 .{ }^{6}$

\begin{tabular}{c|c}
\hline Element & Status \\
\hline COMPAREE & pronoun, noun \\
\hline STANDARD & pronoun, noun \\
\hline PARAMETER & adjective, noun, verb \\
\hline $\begin{array}{c}\text { STANDARD MARKER } \\
\text { (S-MARK) }\end{array}$ & noun (adverb/adverbial demonstrative \\
followed by-fe (CLF:SIDE) and -mo (LOC)
\end{tabular}

Table 2. Syntactic status of elements of Murui comparative constructions

As mentioned in section 1, adjectives (followed by classifiers) can be used as an argument of a verbless clause, such as ebikaiai 'beautiful (fingers)' in (13), or as a head of an intransitive clause, such as ebirede '(they) are beautiful' in (14). The semantic difference between (13-14) relates to the temporality of attribution (see also examples (4-5) in $\$ 2$ ).
oo-kai-a $\dot{\mathrm{v}}_{\mathrm{VCS}} \quad$ ebi-kai-ai $\dot{\mathrm{v}}_{\mathrm{VCC}}$
verbless clause - 'timeless'
2sg-CLF:STEM-PL nice-CLF:STEM-PL
'Your (fingers) are beautiful (lit. your (fingers) - nice (fingers)).' (e.g. they are long and straight)
'Your (fingers) are beautiful (lit. your (fingers) have a property of being nice).'
(e.g. they are decorated with rings)

A similar two-fold division can be made for the comparative constructions. Those comparative constructions that involve verbless clauses with adjectives which have grammatical properties similar to nouns (and refer to 'timeless' attribution), as in (13), I will call 'type 1'. Those that involve adjectives functioning as intransitive predicates (and refer to 'temporal' attribution), as in (14), I will call 'type 2'. Constructions of those types are most commonly used for comparison. This is illustrated by the set of examples in (15) and (16) below. In (15), the adjective root jano'small' followed by a classifier functions as a verbless copula complement (see also section 4 on superlative strategies). (16), with the STANDARD kue 'I' and the S-MARK baaifemo 'ahead (of)', is a comparative construction of type 1 .
$\begin{array}{lll}\text { nai-ñaiño } & \text { (eo) } & \text { jano-ñaiño } \\ \text { ANA.SP-CLF:PR.F } & \text { very } & \text { small-CLF:PR.F }\end{array}$
'She is very small (lit. she - very small (female)).'

${ }^{6}$ For the terminology used throughout this paper see the introduction (Treis, this volume). 
(16)

\begin{tabular}{|c|c|c|c|c|}
\hline COMPAREE & P-MARK & PARAMETER & STANDARD & S-MARK \\
\hline nai-ñaiño ${ }_{v c s}$ & (eo) & jano-ñaiño ${ }_{\mathrm{VCC}}$ & [kue & baai-fe-mo $]_{\mathrm{NP}: \text { PERF }}$ \\
\hline ANA.SP-CLF:PR.F & very & small-CLF:PR.F & $1 \mathrm{sg}$ & ahead-CLF:SIDE-LOC \\
\hline
\end{tabular}

Murui has several means for expressing comparison. All are monoclausal, where the PARAMETER is stated only once; the STANDARD and the S-MARK of comparison are peripheral elements. The COMPAREE functions as either a verbless copula subject (VCS) or a subject of intransitive clause. Murui comparative constructions can be distinguished by:

1) forms of the S-MARK, which can be either: 1) an adverb or an adverbial demonstrative followed by -fe-mo (-CLF:SIDE-LOC), 2) emodo-mo 'over' (over-LOC), or 3) an argument followed by the locative $-m o$,

2) grammatical properties of the PARAMETER of comparison, which can be expressed either as an argument of a verbless clause (type 1) or a head an intransitive predicate (type 2).

There is a strong tendency for the PARAMETER to be an adjective; in addition, nouns and verbs can function as the PARAMETER as well. The optional P-MARK, eo 'very, a lot' is an intensifier. The comparative constructions with -femo $(\S 3.1)$ are common; those with emodomo $(\S 3.3)$ are used less often, and those that involve the locative $-m o(\$ 3.4)$ are rare in everyday discourse. Murui comparative constructions with -femo are illustrated in Tables 3-5. Each table displays the most common ordering of structural elements for a given comparative construction, as well as their usage in everyday conversations. Forms of the S-MARK -femo are shown in Table 6 in $\$ 3.2$.

\begin{tabular}{c|c|c|c|c|c|c}
\hline $\begin{array}{c}\text { Type and } \\
\text { meaning }\end{array}$ & COMPAREE & P-MARK & PARAMETER & STANDARD & S-MARK & USAGE \\
\hline type 1 'timeless' & VCS & $\begin{array}{c}\text { PARAMETER preceded by } \\
\text { optional intensifier } e o \\
\text { 'very' }\end{array}$ & VCC & NP & $\begin{array}{c}\text { oblique } \\
\text { NP }\end{array}$ & $\begin{array}{c}\text { common } \\
\text { type 2 'temporal' }\end{array}$ \\
\hline S & $\begin{array}{c}\text { PARAMETER preceded by } \\
\text { optional intensifier } e o \\
\text { 'very' }\end{array}$ & $\begin{array}{c}\text { intransitive } \\
\text { predicate }\end{array}$ & NP & $\begin{array}{c}\text { oblique } \\
\text { NP }\end{array}$ & \begin{tabular}{c} 
common \\
\hline
\end{tabular}
\end{tabular}

Table 3. Comparative constructions with S-MARK -femo and their usual structural slots $(\$ 3.1)$

\begin{tabular}{c|c|c|c|c|c|c}
\hline $\begin{array}{c}\text { Type and } \\
\text { meaning }\end{array}$ & COMPAREE & STANDARD & S-MARK & P-MARK & PARAMETER & USAGE \\
\hline $\begin{array}{c}\text { type } 1 \\
\text { timeless' }\end{array}$ & VCS & NP & $\begin{array}{c}\text { oblique } \\
\text { NP }\end{array}$ & $\begin{array}{c}\text { PARAMETER preceded } \\
\text { by optional intensifier } \\
\text { eo 'very' }\end{array}$ & VCC & occasional \\
\hline $\begin{array}{c}\text { type } 2 \\
\text { temporal' }\end{array}$ & $\mathrm{S}$ & $\mathrm{NP}$ & $\begin{array}{c}\text { oblique } \\
\text { NP }\end{array}$ & $\begin{array}{c}\text { PARAMETER preceded } \\
\text { by optional intensifier } \\
\text { eo 'very' }\end{array}$ & $\begin{array}{c}\text { intransitive } \\
\text { predicate }\end{array}$ & occasional \\
\hline
\end{tabular}

Table 4. Comparative constructions with the S-MARK emodomo and their usual structural slots ( 33.3$)$ 


\begin{tabular}{c|c|c|c|c|c}
\hline $\begin{array}{c}\text { Type and } \\
\text { meaning }\end{array}$ & STANDARD & COMPAREE & P-MARK & PARAMETER & USAGE \\
\hline type 1 'timeless' & oblique NP & VCS & $\begin{array}{c}\text { PARAMETER preceded by optional } \\
\text { intensifier } e o \text { 'very' }\end{array}$ & VCC & rare \\
\hline
\end{tabular}

Table 5. Comparative constructions with the S-MARK -mo and their usual structural slots $(\S 3.4)$

\subsection{Comparatives with -femo}

Comparative construction with the S-MARK -femo involve two construction types, those of type 1 and type 2. Those of type 1 involve verbless clause constructions, where the COMPAREE, STANDARD, and PARAMETER of comparison are nouns and refer to 'timeless attribution' of a referent, as in (17). Constructions of type 2 involve adjectives that function as heads of intransitive predicates (occasionally, also verbs and nouns), and refer to 'temporal attribution', as in (18). The STANDARD and the S-MARK always form an NP.

\begin{tabular}{|c|c|c|c|c|c|}
\hline MPAREE & & P-MARK & PARAMETER & STANDARD & S-MARK \\
\hline bi-e & $\begin{array}{l}\text { iii-ma] }]_{\mathrm{VCS}} \\
\text { man-CLF:DR.M }\end{array}$ & & $\begin{array}{l}\text { aiyo-mie }{ }_{\mathrm{vCC}} \\
\text { big-CLF:PR.M }\end{array}$ & $\begin{array}{l}\text { [bi-mie } \\
\text { this-CLF:PR.M }\end{array}$ & ba \\
\hline
\end{tabular}

$\begin{array}{llll}\text { COMPAREE } & \text { STANDARD } & \text { S-MARK } & \text { PARAMETER } \\ \text { kue }_{\mathrm{s}} & {[\text { oo }} & \text { ana-fe-mo }]_{\text {NP:PERF }} & \text { ia-mie-di-kue } \\ \text { 1sged } & 2 \mathrm{sg} & \text { below-CLF:SDE-LOC } & \text { short-CLF:PR.M-LK-1sg } \\ \text { 'I (male) am smaller than you (lit. I - you on the down side, am small).' }\end{array}$

In (19), the PARAMETER of the comparative construction type 1 is a noun uaikima 'old man'. (20) is its negated counterpart where the noun is used as a head of a negated intransitive predicate. Examples such as (20) are not common; usually the STANDARD and S-MARK are not expressed when the comparative constructions are negated.

$\begin{array}{lllll}\text { COMPAREE } & \text { P-MARK } & \text { PARAMETER } & \text { STANDARD } & \text { S-MARK } \\ \text { Jose }_{\mathrm{vCS}} & \text { eo } & \text { uaiki-ma } & \text { [Caro } & \text { baaí-fe-mo }]_{\mathrm{NP}: \text { PERF }} \\ \text { Jose } & \text { very } & \text { aged-CLF:DR.M } & \text { Carlos } & \text { ahead-CLF:SIDE-LOC }\end{array}$

\begin{tabular}{|c|c|c|c|}
\hline COMPAREE & PARAMETER & STANDARD & S-MARK \\
\hline $\begin{array}{l}\text { Jose }_{\mathrm{s}} \\
\text { Jose }\end{array}$ & $\begin{array}{l}\text { uaikit-ma-ñe-d-e } \mathrm{e}_{\text {PRED }} \\
\text { aged-CLF:DR.M-NEG-LK-3 }\end{array}$ & $\begin{array}{l}{[\text { Caro }} \\
\text { Carlos }\end{array}$ & $\begin{array}{l}\text { baai-fe-mo }]_{\text {NP:PERF }} \\
\text { ahead-CLF:SIDE-LOC }\end{array}$ \\
\hline
\end{tabular}

The S-MARK of comparison is a noun formed from adverbial demonstratives (e.g. baai 'ahead, over there') or adverbs of place, such as foo 'inside' (see $\$ 3.2$ on forms of s-MARK). S-MARK can have various forms whose meanings are related to distance, interiority, and vertical position, as in examples (21-22): 
(21)

\begin{tabular}{|c|c|c|c|c|}
\hline & P-MARK & & STANDARD & S-MARK \\
\hline & & $\begin{array}{l}\text { jano-ñaiño } \\
\text { vmall-CLF }\end{array}$ & [kue & baai-fe-mo $]_{\mathrm{NP}: \mathrm{ERF}}$ \\
\hline
\end{tabular}

'She is smaller than me (lit. she - very small, ahead of me).'

$\begin{array}{lllll}\text { COMPAREE } & \text { P-MARK } & \text { PARAMETER } & \text { STANDARD } & \text { S-MARK } \\ \text { nai-ñaiño } & \text { eo } & \text { jano-ñaiño }_{\mathrm{vCC}} & {[\mathrm{kue}} & \text { foo-fe-mo }]_{\mathrm{NP} \text { :PERF }} \\ \text { ANA.SP-CLF:PR.F } & \text { very } & \text { small-CLF:PR.F } & 1 \mathrm{sg} & \text { inside-CLF:SIDE-LOC }\end{array}$

'She is smaller than me (lit. she - very small, me on the inside).'

Sometimes, in the constructions type 1, the PARAMETER can be postposed to the STANDARD. In (23), the STANDARD of comparison, the noun aiyo-kae 'big (canoe)' and the S-MARK baaifemo 'ahead (of)', are followed by the PARAMETER aiyue 'big' in the VCC function. The COMPAREE is the NP aiyue raya 'big boat'. Such ordering of constituents in the sentence is always pragmatically conditioned and occurs when there is an extra emphasis on the STANDARD.

\begin{tabular}{|c|c|c|c|c|c|}
\hline $\mathrm{EE}$ & & $\mathrm{RD}$ & S-MARK & $\mathrm{K}$ & TER \\
\hline & $\begin{array}{l}\text { ra-ya] }]_{\mathrm{VCS}} \\
\text { thing-CLF:CRAFT }\end{array}$ & $\begin{array}{l}\text { [aiyo-kae } \\
\text { big-CLF.REP:CANOE }\end{array}$ & $\begin{array}{l}\text { baat-fe-mo }]_{\mathrm{NP} P \text { PERF }} \\
\text { ahead-CLF:SIDE-LOC }\end{array}$ & $\begin{array}{l}{[\text { eo }} \\
\text { very }\end{array}$ & $\begin{array}{l}\text { a1yue] }]_{\text {vCC }} \\
\text { big.CLF:G }\end{array}$ \\
\hline
\end{tabular}

'Big boats are bigger than big (canoes) (lit. big boats - ahead of big (canoes) - very big).'

In comparative constructions type 2, adjectives, nouns, and verbs function as heads of an intransitive predicate. In (24), the PARAMETER of comparison is an intransitive predicate mokorede 'green' modified by the P-MARK eo 'very':

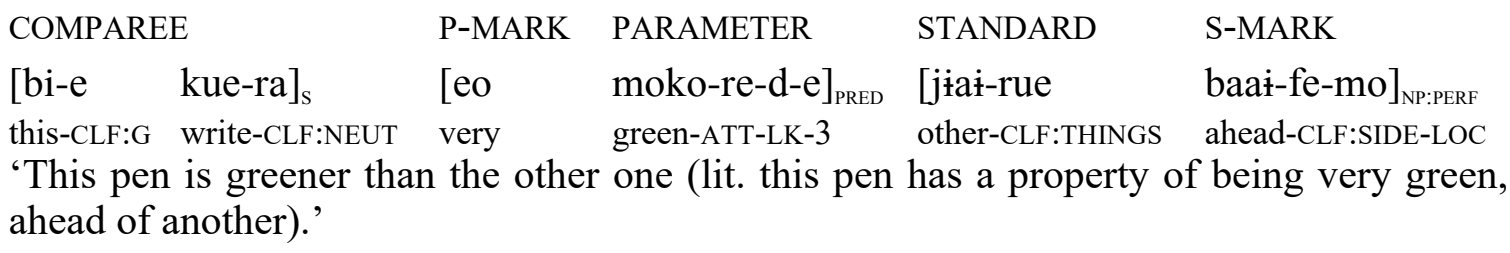

In (25), the PARAMETER mare-ñaiño-di-kue 'I'm (a) beautiful (female)' is a nominalised adjective mare 'good, beautiful' followed by the animate classifier -ñaino, and it functions as a head of an intransitive predicate. The STANDARD of comparison is the third person pronoun followed by the S-MARK baaifemo 'ahead (of)': 7

\begin{tabular}{|c|c|c|c|c|}
\hline OMPAREE & P-MARK & PARAMETER & STANDARD & S-MARK \\
\hline $\mathrm{ue}_{\mathrm{s}}$ & & $\begin{array}{l}\text { mare-ñaiño-di-kue }{ }_{\text {PRED }} \\
\text { good.ATT-CLF:PR.F-LK-1 } \text { sg }^{8}\end{array}$ & $\begin{array}{l}\text { ñaiño } \\
\text { LLF:PR.F }\end{array}$ & $\begin{array}{l}-\mathrm{mo}]_{\mathrm{NP}: \text { PERF }} \\
\text { LF:SIDE-LOC }\end{array}$ \\
\hline
\end{tabular}

'I am more beautiful than her (lit. I am very good, ahead of her).'

\footnotetext{
${ }^{7}$ 'Self-praising', as in (25), is not a usual practise among the Murui. This has to do with the cultural aversion against individualisation, 'me' kue $(1 \mathrm{sg})$ vs. 'we' kai $(1 \mathrm{pl})$. The traditional Murui speakers always talk in pluralistic terms recognising the contributions of the people (i.e. $k a$ ) , and never promoting an individual (i.e. $k u e$ ).

${ }^{8}$ The adjective mare 'good' can also mean 'beautiful', especially when referring to persons.
} 
Similar is (26), where the PARAMETER of comparison, the noun $u k u b e$ 'money', functions as a predicate head followed by the STANDARD and the S-MARK:

COMPAREE

[bi-e feka-ra-ko

this-CLF:G divide-CLF:NEUT-CLF:COVER

$$
\text { naama }=\mathrm{dij}]_{\mathrm{S}}
$$

owner $=$ S/A.TOP
P-MARK PARAMETER

eo

very uku-be-re-d-e $\mathrm{e}_{\text {PRED }}$ plant-CLF:LEAF-ATT-LK-3

$\begin{array}{ll}\text { STANDARD } & \text { S-MARK } \\ \text { [jiai-mie } & \text { baai-fe-mo }]_{\text {NP:PERF }} \\ \text { other-CLF:PR.M } & \text { ahead-CLF:SIDE-LOC }\end{array}$

'This store owner is richer than the other one (lit. this store owner has a lot of money, ahead of the other (male)).'

The following examples illustrate the intransitive verbal root kio- 'see' and the transitive roko'cook' in the PARAMETER function. In (28), the COMPAREE is a pronominal S/A subject marker -kue $(1 \mathrm{sg})$ :

\begin{tabular}{lllll} 
COMPAREE & \multicolumn{2}{l}{ PARAMETER } & STANDARD & S-MARK \\
nai-ñaiño & raize & $[$ kio-d-e $]]_{\text {PRED }}$ & {$[\mathrm{kue}$} & baai-fe-mo $]_{\text {NPPPRF }}$ \\
ANA.SP-CLF:PR.F & well.ATT & see-LK-3 & $1 \mathrm{sg}$ & ahead-CLF:SIDE-LOC
\end{tabular}

'She sees better than I do (lit. she sees well, ahead of me).'

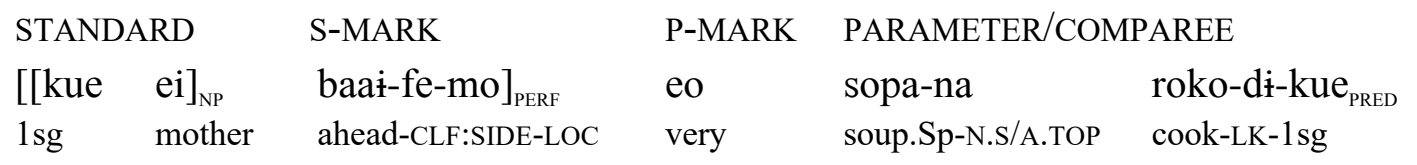

'I cooked more soup than my mother (lit. ahead of my mother, I cook a lot of soup).'

The COMPAREE and the STANDARD of comparison can be further modified by means of dependent clauses, as in (29). The non-singular reading of baiko 'these (dogs)' is contextual.

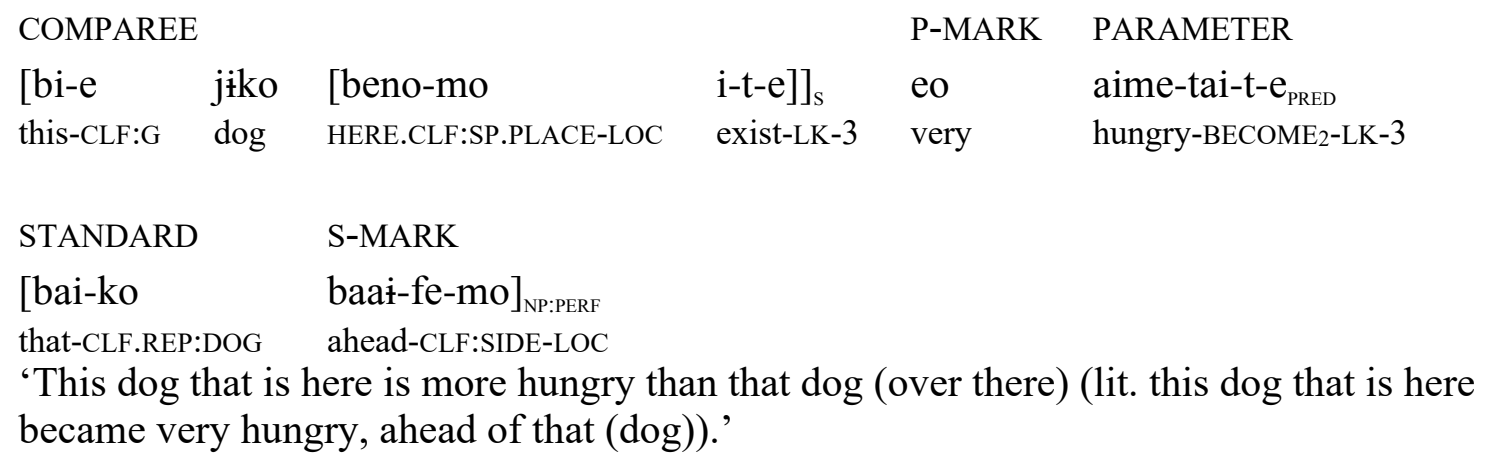

\subsection{The standard marker $-f e m o$}

In comparative constructions with -femo (see $\S 3.1$ ), the S-MARK of comparison is a noun formed with either the adverbial demonstrative baai 'ahead, over there' or a restricted set of place adverbs. They are always followed by the word class changing $-f e$ and the locative case marker $-m o$. The forms of S-MARKS are outlined in Table 6. By far, the most common form of the S-MARK -femo is 
baaifemo 'ahead (of)' expressing relative superiority 'more', and its 'negative' equivalent foofemo 'on the inside (of)' used for expression of relative inferiority 'less'.

The meanings of the -femo forms relate to distance ('ahead'), interiority ('inside' and 'outside'), and vertical position ('low' and 'high'). ${ }^{9}$ Such semantic division of the S-MARK indicates the importance of object's physical properties in terms of their shape and position in space in Murui. For instance, nouns formed with the classifier -bogi for 'big ball-like objects' are referred to with the S-MARK jinofemo 'wider (lit. on the outside)' when compared with -dozi 'thin stick' (see Diagram 1 further this section).

\begin{tabular}{l|l|l|l}
\hline MARK & Gloss & Literal meaning & Reading \\
\hline baai-fe-mo & ahead-CLF:SIDE-LOC & 'ahead (of), on the ahead side (of)'10 & 'more' \\
\hline foo-fe-mo & inside-CLF:SIDE-LOC & 'on the inside (of)' & 'less, slimmer' \\
\hline$a a-f e-m o$ & above-CLF:SIDE-LOC & 'on the top side (of)' & 'higher' \\
\hline ana-fe-mo & below-CLF:SIDE-LOC & 'on the down side (of)' & 'lower' \\
\hline jino-fe-mo & outside-CLF:SIDE-LOC & 'on the outside (of)' & 'wider' \\
\hline \multicolumn{2}{|c|}{ Table 6. Forms of the s-MARK -femo in Murui comparative constructions }
\end{tabular}

Nowadays, all five forms of the S-MARK are almost exclusively used by older speakers of the language. Among younger speakers, baaifemo 'ahead (of)', and, to an extent, foofemo 'on the inside (of)', are robustly productive; other forms are falling out of use.

The roots of the S-MARK are not unique to comparative constructions, and elsewhere in the language they can be used as demonstratives and adverbs with locational meanings: They are independent forms which cannot be case-marked unless they take the classifier $-f e$ (see Wojtylak 2017 for details). Examples of this are given in (30-35). Nouns formed with $-f e$ can be followed by other (physical property) classifiers, as in (33).

$$
\begin{array}{ll}
\text { baai }=\text { dino } & \text { i-t-e } \mathrm{e}_{\text {PRED }} \\
\text { ahead=AT.CLF:SP.PLACE } & \text { exist-LK-3 }
\end{array}
$$

'(A person) is over there (lit. ahead of you in that place).'

(31) baai-fe i-ñe-d-e PRED $_{\text {Pe }}$ ahead-CLF:SIDE exist-NEG-LK-3 '(It) does not have an end (lit. the point ahead doesn't exist).'
uzu-ma $a_{\mathrm{S}} \quad$ kaima-re foo bi-t- $\mathrm{e}_{\text {PRED }}$
grandparent-CLF:DR.M happy-ATT inside come-LK-3
'The grandfather happily came inside.'

(33) foo-fe-be-niai

inside-CLF:SIDE-CLF:LEAF-COLL

'interior side (of leaves, of paper sheets, etc.)'

\footnotetext{
${ }^{9}$ The S-MARK foofemo 'on the inside (of)' has a form of $j o-f o-f e-m o$ (with the unanalysable element $j o-$ ) in Minika (another variety of Witoto). The form jo- is possibly related to the 1sg pronoun kue (cf. xõ in Ocaina and jo'é in Nonuya). All Witotoan languages have the classifier - $f o$ 'hole-like, cavity' which is related to the adverb foo 'inside'. ${ }^{10}$ Throughout this paper, I chose to translate baaifemo (lit. on the ahead side) as 'ahead (of)'.
} 

[ana-fe
dine-na] aa
nuita! ${ }_{\text {PRED }}$
below-CLF:SIDE AT.CLF:NSP-ABL above
push.IMP

'Push from (the side) below upwards!'
jino jaai-ño-kai! ${ }_{\text {PRED }}$
outside go-IMP-RAPID
'Go quickly outside!'

The semantics of the S-MARK forms allow a division between two parallel types of comparative constructions: those that express superiority, and those which convey the notions of inferiority, as illustrated in Diagram 1 below. ${ }^{11}$ The S-MARKS expressing superiority make more distinctions than those expressing inferiority. ${ }^{12}$

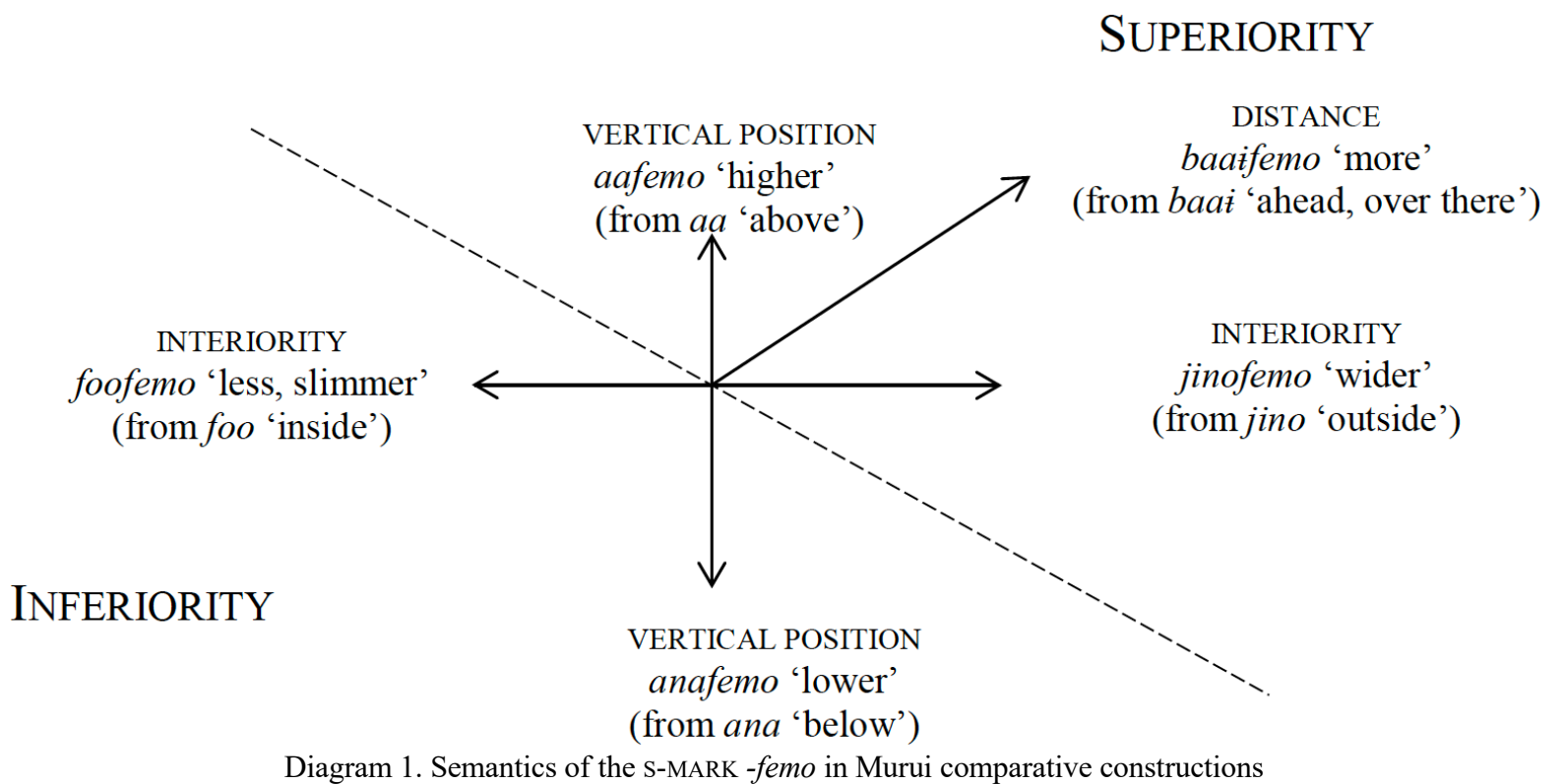

I. COMPARISON OF SUPERIORITY - comparison of superiority in Murui relates to the notions of vertical position ('higher' < 'above'), distance ('more' < 'ahead, over there'), and interiority (or measurement: 'wider' < 'outside'). The most prevalent S-MARK referring to superiority involves distance, and is formed with the adverbial demonstrative baai 'ahead, over there' followed by $-f e$ and the locative -mo. In the speech of Murui elders, baaifemo marks only those types of comparison that refer to distance; among younger speakers, it is also used for expressing interiority and vertical position. Throughout the paper, I give various examples of comparative constructions with baaifemo, including comparison of property, as in $(21,25)$, quality, as in (27), and quantity, as in (28).

\footnotetext{
${ }^{11}$ 'Superiority' and 'inferiority' are understood here in terms of the position in space, rather than expressing 'more' and 'less'. That way, the forms of the S-MARK mark 'higher degree of a property', which can be either superior or inferior. For instance, when the inferiority S-MARK foofemo 'on the inside (of)' occurs with the adjective 'small', it expresses 'higher degree of smallness', rather than simply 'less small, lower degree of smallness'.

${ }^{12}$ This is somewhat different from Yalaku (Aikhenvald, this volume). In addition to biclausal constructions, Yalaku also uses a strategy involving directional verbs. While there is only one verb used to express superiority ('go up'), expression of inferiority involves two distinct verbs ('go down' and 'go down slope').
} 
In traditional Murui, interiority and vertical position are important parameters that define the form of the S-MARK. The form aafemo 'higher (lit. on the top side)' describes superiority of an object's property on a vertical plane. Examples are given in (36-37):

\begin{tabular}{|c|c|c|c|c|}
\hline COMPAREE & P-MARK & PARAMETER & STANDARD & S-MARK \\
\hline$e_{s}$ & eo & aare-ñaiño-di-kue $e_{\mathrm{PRED}}$ & [nai-maki & aa-fe-mo $]_{\mathrm{NP}: P E R F}$ \\
\hline sg & very & long-CLF:PR.F-LK-1sg & ANA.SP-CLF:PR.GR.AN & above-CLF:SIDE-LOC \\
\hline
\end{tabular}

$\begin{array}{lllll}\text { COMPAREE } & \text { STANDARD } & \text { S-MARK } & \text { PARAMETER } \\ {[\mathrm{kai}} & \text { jo-fo }]_{\mathrm{VCS}} & {[\text { oo-ie }} & \text { aa-fe-mo }]_{\mathrm{NP}: \text { PERF }} & \text { aare } \\ 1 \mathrm{pl} & \text { house-CLF:CAVITY } & \text { 2sg-GEN } & \text { above-CLF:SIDE-LOC } & \text { long }\end{array}$

'Our house is taller than yours (lit. our house, yours on the top side, long).'

Marking of interiority in comparative constructions indicates that an object is seen from either outside (viewed as being 'superior', for which jinofemo 'wider (lit. on the outside)' is used) or inside (viewed as being 'inferior', which is marked with foofemo 'less, slimmer (lit. on the inside)'). The S-MARK jinofemo is used to refer to an object that is physically wider (horizontally, in terms of its size), as illustrated in (38-39):

$\begin{array}{llll}\text { COMPAREE } & \text { STANDARD } & \text { S-MARK } & \text { PARAMETER } \\ \text { ria-ma }_{\text {VCS }} & {[\mathrm{kai}} & \text { jino-fe-mo }]_{\text {PERF }} & \text { fare-bogi } \\ \text { nonWitoto-CLF:DR.M } & 1 \mathrm{pl} & \text { outside-CLF:SIDE-LOC } & \text { fat-CLF:BIG.ROUND }\end{array}$

'The white man is bulkier than us (lit. white man, us on the outside, fat (ball-like)).'
COMPAREE
STANDARD S-MARK
P-MARK PARAMETER
$\begin{array}{lll}\text { [jo-fo } & \text { naa-ño } & \\ \text { house-CLF:CAVITY } & \text { owner-CLF:DR.F } & \text { Kata }\end{array}$
jino-fe-mo $]_{\mathrm{NP}: \mathrm{PERF}} \quad$ eo
outside-CLF:SIDE-LOC very
aiyo-ñaiño $_{\mathrm{vCC}}$
'The (female) owner of the house is bigger than Kata (lit. the (female) house owner, Kata
on the outside, big (female)).'

That the use of S-MARKS referring to vertical positon and interiority is almost exclusively a feature of the speech of Murui elders, might possibly indicate that in the past, comparative constructions might have involved an extensive use of different types of markers of comparison. ${ }^{13}$

II. COMPARISON OF INFERIORITY - comparison of inferiority involves interiority ('inside') and vertical position ('low'). By far, interiority is the most prevalent notion expressing 'less'. Among younger speakers, the S-MARK foofemo (formed with foo 'inside') is used to refer to all types of comparison of inferiority, as in (40-42) below:

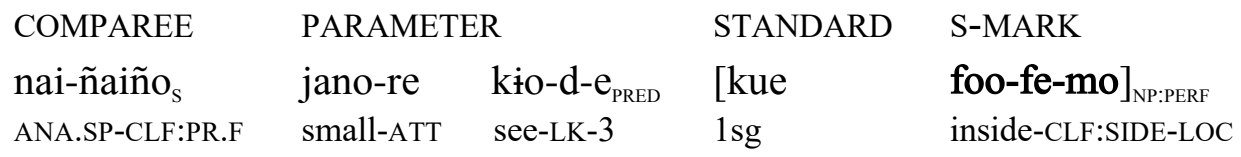

'She sees less than me (lit. she sees little, me on the inside).'

\footnotetext{
${ }^{13}$ Possibly, the topographic adverbs of place afai 'upstream' and fuirt 'downstream'.
} 


$\begin{array}{llll}\text { COMPAREE } & \text { STANDARD } & \text { S-MARK } & \text { PARAMETER } \\ \text { pila-ji }=\mathrm{di}_{\mathrm{S}} & {[\text { mechera }} & \text { foo-fe-mo }]_{\mathrm{NP} P \text { PERF }} & \text { jano-re-d- } \mathrm{e}_{\text {PRED }} \\ \text { battery.Sp-CLF:SMALL.ROUND=S/A.TOP } & \text { lighter.Sp } & \text { inside-CLF:SIDE-LOC } & \text { small-ATT-LK-3 } \\ \text { 'The battery is smaller than the lighter (lit. the battery, the lighter on the inside, is small).' }\end{array}$

$\begin{array}{llll}\text { [nai-e } & \text { dio-kaì }]_{S} & \text { raize } & \text { aa } \\ \text { ANA.SP-CLF:G } & \text { tobacco-CLF:STEM } & \text { well.SIMIL } & \text { above }\end{array}$

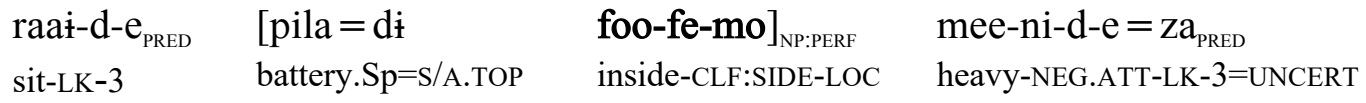

'The cigarette is less steady than the battery as (the cigarette) is not heavy (lit. the cigarette sits well up there; the battery on the inside; (the cigarette) is not heavy).'

When referring to objects located in space expressing ' $y$ less than x' meanings, Murui elders tend to use the S-MARK anafemo for 'lower', as exemplified in (43). This is unlike young Murui speakers, who employ foofemo 'inside (of)' at all times.

\begin{tabular}{|c|c|c|c|}
\hline COMPAREE & PARAMETER & STANDARD & S-MARK \\
\hline $\mathrm{kue}_{\mathrm{s}}$ & ia-ñaiño-di-kue ${ }_{\mathrm{PRED}}$ & [Sandriela & ana-fe-mo $]_{\mathrm{NP}: \mathrm{PERF}}$ \\
\hline & short-CLF:PR.F-LK-1sg & Sandriela & below-CLF:SIDE-LOC \\
\hline
\end{tabular}

\subsection{Comparatives with emodomo}

Another type of Murui comparative constructions involves the S-MARK emodomo, and is used for comparison of superiority (see Wojtylak forthcoming on the grammaticalization of the body part term 'back, spine' into a marker of comparative constructions). Unlike the comparatives involving S-MARK -femo (see §3.1-2), comparatives marked with emodomo are not used often. Similarly to comparative constructions involving -femo, comparatives with emodomo are monoclausal, and distinguish between clauses with 'temporal' and 'timeless' semantics. In such constructions, the COMPAREE and STANDARD are expressed by adjectives, verbs, and nouns that function as heads of intransitive predicates. The S-MARK of comparison emodomo is best interpreted as 'over, on top, above'; it is formed with the noun emodo 'back' (cf. (47)) followed by the locative -mo. The PMARK eo 'very, a lot' is optional. This is illustrated in (44-45) below:

$\begin{array}{lllll}\text { COMPAREE } & \text { STANDARD } & \text { S-MARK } & \text { PARAMETER } \\ \text { [bai-e } & \text { anane-ko }]_{\mathrm{S}} & {[\text { bi-e }} & \text { emodo-mo }]_{\text {NP:PERF }} & \text { maraiñe-d-e } \\ \text { that-CLF:G } & \text { maloca-CLF:COVER } & \text { this-CLF:G } & \text { over-LOC } & \text { good.ATT.NEG-LK-3 }\end{array}$

'That maloca is not better than this one (lit. that maloca, over this (one), is not good).'

\begin{tabular}{llllll} 
COMPAREE & & \multicolumn{2}{l}{ STANDARD } & S-MARK & PARAMETER \\
[bi-e & raai-ra-ko $]_{\mathrm{VCS}}$ & {$[$ oni } & bi-e & emodo-mo $]_{\mathrm{NP}: \text { PERF }}$ & aiyue $_{\mathrm{VCC}}$ \\
this-CLF:G & sit-CLF:NEUT-CLF:COVER & LOCAL & this-CLF:G & over-LOC & big.CLF:G
\end{tabular}

'This seat is bigger than this seat here (lit. this seat, over this one here, big).' 
For more emphasis, the ordering of the COMPAREE and STANDARD can be reversed, and the STANDARD is preposed to the COMPAREE. Such types of comparative constructions are used relatively often in the everyday conversations. They are found mostly when comparing inanimate objects. An example is given in (46):

$\begin{array}{llll}\text { COMPAREE } & \text { STANDARD } & \text { S-MARK } & \text { PARAMETER } \\ \text { Jose }_{\mathrm{VCS}} & {[\text { Pedro }} & \text { emodo-mo }]_{\mathrm{NP}: \text { PERF }} & \text { aare-mie }_{\mathrm{VCC}} \\ \text { Jose } & \text { Pedro } & \text { over-LOC } & \text { long-CLF:PR.M } \\ \text { 'Jose is taller than Pedro (lit. Jose, over Pedro, long (male).)' }\end{array}$

The S-MARK emodomo is not unique to comparative constructions. In (47), emodo followed by the locative -mo, means 'on (the) back':

$$
\begin{array}{llll}
{[\text { kue }} & \text { emodo-mo }_{\text {NP:PERF }} & \begin{array}{l}
\text { kiri-tiko } \\
\text { basket- }
\end{array} & \text { yïi-ya }_{\text {PRED }} \\
\text { cLf:SMALLER } & \text { back-LOC } & \text { grab-EVENT.NMLZ }
\end{array}
$$

'(I) carry a small basket on my back.'

Elsewhere in the grammar, emodomo is also used for counting, e.g. da-be-kuiro emodo-mo mena (one-CLF:LEAF-CLF:PEEL over-LOC two) for 'seven (lit. one leaf peel over two)' (Wojtylak forthcoming).

The difference between those comparative constructions involving -femo and those marked with emodomo is semantic, as well as pragmatic. People usually interpret emodomo 'over' as having a transparent meaning (referring to one's back), and being 'somewhat stronger' than -femo. Others prefer not to use it, indicating that such constructions are not Murui, but Minika in origin $($ see $§ 1) .{ }^{14}$

\subsection{Comparative with locative -mo}

In addition to the comparative constructions with -femo (\$3.1) and emodomo (§3.3), Murui also has a marginally occurring monoclausal construction that involves a juxtaposition of two NPs; the first NP is always marked with the locative -mo. Its readings impute opposite properties to two inanimate participants. They are reminiscent of other comparative construction types in the use of the locative -mo. Notably, comparative constructions with the locative -mo are rarely used in everyday discourse. ${ }^{15}$ The intensifier eo 'very' is optional. An example is given in (48):

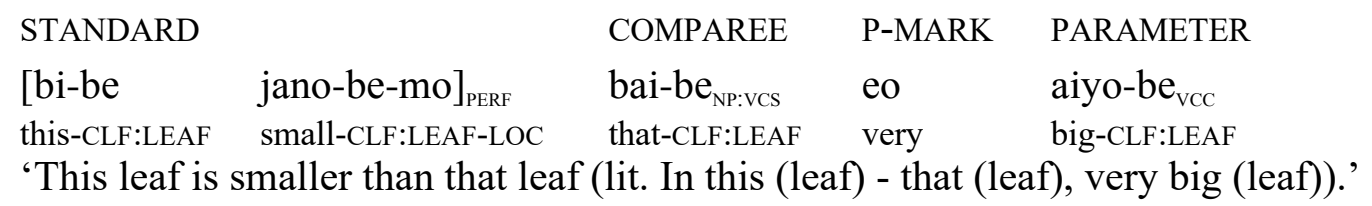

\footnotetext{
${ }^{14}$ The distribution between those comparative constructions marked with -femo and those involving emodomo requires further study.

${ }^{15} \backslash$ They might in fact be a type of an incipient comparative construction where the existing S-MARKS undergo reduction and are represented solely by the locative -mo.
} 


\section{Superlative strategies}

Murui has two independent strategies to indicate superlative meanings. One is contextual, where a simple use of an adjective, a noun, or a verb preceded by the intensifier eo 'very' is interpreted as having a superlative reading. The second strategy involves modification of a noun to indicate a set of referents.

I. SUPERLATIVE INTERPRETATION - depending on the situation and context, constructions that involve the intensifier eo (cf. (4-5) in §2) can have implicit superlative readings (see Vuillermet, this volume, for a similar strategy in Ese Eja). This is illustrated in (49-50):

\begin{tabular}{llll}
\multicolumn{2}{c}{ COMPAREE } & P-MARK & PARAMETER \\
{$[\mathrm{kue}$} & ñoo $]_{\mathrm{VCS}}$ & eo & mare-ñaiño \\
1sg & CLF:DR.F.ENDEAR & very & good.ATT-CLF:PR.F
\end{tabular}

'My daughter is the most beautiful one (lit. my daughter - very good (female)).' (a proud mother discussing a picture of her daughter dancing with other girls)

$\begin{array}{llll}\text { COMPAREE } & \text { P-MARK } & \text { PARAMETER } \\ {[\text { bi-e }} & \text { ra-dozi }]_{\mathrm{VCS}} & \text { eo } & \text { ia-dozi } \\ \text { this-CLF:G } & \text { thing-CLF:STICK } & \text { very } & \text { short-CLF:STICK }\end{array}$

'This stick is the smallest (lit. this stick - short (stick)).' (when holding a bunch of sticks of various lengths)

Often, such constructions are additionally accompanied by an oblique argument marked with the ablative -mona to specify the author of a statement. This is illustrated in (51-53):

$$
\begin{array}{llll}
\text { nai-mie }_{\mathrm{vCS}} & \text { eo } & \text { aiyo-mie }_{\mathrm{VCC}} & \text { oo-mona } \\
\text { ANA.PP-CLF:PR.M } & \text { very } & \text { big-CLF:PR.M } & \text { 2sg-ABL }
\end{array}
$$

'As for you (you think that), he is big.' or 'As for you, he is the biggest.'

$$
\begin{array}{lll}
\text { Maria-mona }_{\mathrm{NP} P \text { PERF }} & \text { eo } & \text { uiño-di- } \\
\text { Maria-ABL } & \text { very } & \text { know-LK-2sg }
\end{array}
$$

'As for Maria (Maria thinks that), you know a lot.' or 'As for Maria, you know the most.'

$$
\begin{aligned}
& \text { nai-maki-mona }{ }_{\mathrm{NP} P \text { PRRF }} \text { eo mare-ñaiño-di-O } \mathrm{O}_{\text {PRED }} \\
& \text { ANA.SP-CLF:PR.GR.AN-ABL very good.ATT-ANA.SP-CLF:PR.F-2sg } \\
& \text { 'As for them (they think that), you're very a beautiful (female).' or 'As for them, } \\
& \text { you're the most beautiful (female).' }
\end{aligned}
$$

The frequent usage of constructions with the ablative marker expressing the meaning 'as for' could possibly be the origin of sentences such as in (54) below. They are common among young speakers of Murui but not among elders. Note that the reading of (54) is not 'as for those children (those children think that)'; rather, the ablative marker specifies a set of referents: 
(54)

\begin{tabular}{|c|c|c|c|}
\hline $\begin{array}{l}\text { [bi-e } \\
\text { this-CLF:G }\end{array}$ & $\begin{array}{l}\text { uru-iai-mona }]_{\mathrm{NP} P \text { PERF }} \\
\text { child-CLF:G.PL-ABL }\end{array}$ & $\begin{array}{l}\text { da-za } \\
\text { one-CLF:IMMATURE }\end{array}$ & $\begin{array}{l}\text { gui-aka-ñe-d-e } \\
\text { erED } \\
\text { eat-DES-NEG-LK-3 }\end{array}$ \\
\hline eo & ira-re-d-e $e_{\text {PRED }}$ & & \\
\hline very & sick-ATT-LK-3 & & \\
\hline
\end{tabular}

The use of such constructions in Murui might have been influenced by the Spanish superlative constructions involving de 'of, from, about', as in a sentence ella es la mas linda de todas 'she is most beautiful of all' or de todos los niños, uno no quiere comer 'of all the children, he is the only one who doesn't eat', as in (54).

II. MODIFICATION OF A NOUN TO INDICATE A SET OF REFERENTS - Murui comparative constructions with the S-MARK baaifemo can have superlative readings; in such instances, the STANDARD is specified as a large set of referents against which the COMPAREE is compared, as in (55-56). They are used by young speakers and are reminiscent of Spanish superlative constructions, where the STANDARD is expressed by a noun referring to as a set of referents, as in el abuelo más viejo de todos 'the oldest elder of everybody'. In such constructions in Murui, the COMPAREE is always marked for number (note that elsewhere Murui has optional number marking on the NP, see $\$ 2$ ). Examples are given in (55-56) below:

\begin{tabular}{llllll} 
COMPAREE & P-MARK & PARAMETER & \multicolumn{3}{l}{ STANDARD } \\
kue $_{\mathrm{s}}$ & eo & mare-ñaiño-di-kue & \\
$1 \mathrm{sR}$ & very & good.ATT-CLF:PR.F-LK-1sg & really & ALL & woman-CLF:DR.F-COLL
\end{tabular}

S-MARK

baai-fe-mo $]_{\mathrm{NP}: \text { PERF }}$ ahead-CLF:SIDE-LOC

'I am the most beautiful out of all women (lit. I am very good, ahead of all the women).'

$\begin{array}{lllll}\text { COMPAREE } & \text { STANDARD } & \text { S-MARK } & \text { P-MARK } & \text { PARAMETER } \\ \text { Kata }_{\mathrm{VCS}} & \text { [jiai-ñainuai }_{\text {jiat }} & \text { baai-fe-mo }]_{\mathrm{NP} \text { :PERF }} & \text { eo } & \text { aiyo-ñaiño } \\ \text { Kata } & \text { other-CLF:PR.F.PL } & \text { ahead-CLF:SIDE-LOC } & \text { very } & \text { big-CLF:PR.F }\end{array}$

'Kata is the biggest of all (lit. Kata, over other females, very big (female)).'

\section{Comparison of equality and similative meanings}

In prototypical equative and similative constructions two entities (the COMPAREE and the STANDARD) are ascribed to the PARAMETER to the same or similar extent. Murui equative and similative constructions are discussed in turn. 


\subsection{Equative constructions}

Murui equative constructions are expressed by verbless and (extended) intransitive clauses, where the STANDARD is followed by either the postposition izoi 'similar', as in (57), or the verbal root $i z o i$ - followed by verbal morphology, as in (58). The intensifier eo 'very' is often present.

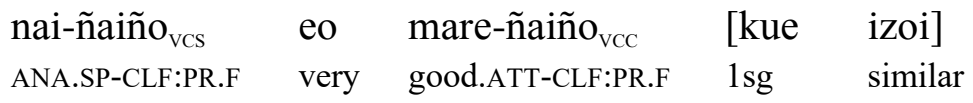

'She is as beautiful as me (lit. she - very good, similar to me).'
[kue niña $]_{S} \quad$ ria-ño ${ }_{E}$
izoi-d- $\mathrm{e}_{\mathrm{PRED}}$
1sg child.Sp.F nonWitoto-CLF:DR.F similar-LK-3

'My child is like a white woman (lit. my child is similar to a white woman).'

Verbless clauses and intransitive clauses can co-occur. This is illustrated in (59):

$$
\begin{array}{llllll}
{[\text { bi-e }} & \text { jo-fo }]_{\text {VCS }} & \text { aiyue }_{\text {VCC }} & \text { [jiai-e } & \text { jo-fo }]_{\mathrm{E}} & \text { izoi-d-e } \\
\text { this-CLF:G } & \text { house-CLF:CAVITY } & \text { big.CLF:G } & \text { other-CLF:G } & \text { house-CLF:CAVITY } & \text { similar-LK-3 }
\end{array}
$$
'This house is as big as the other house (lit. this house - big house, similar to the other house).'

The context can play an important role in interpretation of izoi(de) 'be similar'. The verb is homophonous with the intransitive verb $i$-t-e (exist-LK-3) 'exist, be, live' marked with the remote habitual -zoi, as in (60). From the synchronic perspective, izoi-and $i$ - are not related.
[kue moo mikori $]_{\mathrm{S}}$ iyai-ma-na
i-zoi-d-e PRED $_{\text {PR }}$
1 sg father deceased chief-CLF:DR.M-N.S/A.TOP
exist-REM.HAB-LK-3
'My deceased father used to be a leader.'

Ordering of elements in equative constructions is similar to that of comparative constructions. In Murui, there is a certain flexibility in constituents orders, where the position of the oblique argument can be subject to change (i.e. focus). In (61), the STANDARD is preposed to the PARAMETER:
(61)

$\begin{array}{lllll}\text { nai-ñaiño } & {[\text { kue }} & \text { izoi }]_{\mathrm{E}} & \text { raize } & \text { ro-t-e } \\ \text { ANED } & \\ \text { ANA.SP-CLF:PR.F } & 1 \mathrm{sg} & \text { similar } & \text { well.SIMIL } & \text { sing-LK-3 }\end{array}$
'She sings as well as me (lit. she, similar to me, sings well).'

Murui has also a number of lexical verbs which express transformative-like meanings: jaai(de) 'go, become (in shamanic practices)', janai(de) 'behave in a similar fashion', and i(te) 'exist' (as in (60) above). They are most frequently used in the context of physical and spiritual transformations. The object of transformation is always obligatorily marked with the topical nonsubject marker -na. This is illustrated in (62-63): 
(62)

uzu-ma janayari-na $_{\mathrm{O}}$ jaai-d-e $\mathrm{ePRD}_{\mathrm{PRE}}$

grandfather-CLF:DR.M jaguar-N.S/A.TOP go-LK-3

'The grandfather became a jaguar.' (meaning: the grandfather transformed into a jaguar)

(63)

Alexis $_{\mathrm{A}} \quad$ iyai-ma-na $_{\mathrm{O}} \quad$ janai-d-e $\mathrm{PRED}_{\mathrm{PR}}$

Alexis chief-CLF:DR.M-N.S/A behave.similar-LK-3

'Alexis behaves like a chief.' (meaning: Alexis behaves like a chief, but he is not a leader)

\subsection{Similative -ze with 'equal size' meanings}

Murui has a category which expresses the notion of ' $\mathrm{Y}$ like/as $\mathrm{X}$ in terms of object's size'. The occurrence of the similative $-z e$ is limited to nouns, demonstratives, the question word $n \dot{i}-e\left(\mathrm{Q}_{2}-\right.$ $\mathrm{CLF}: \mathrm{G}$ ) 'which (one)', and the connective ie. For example, ananeko 'maloca (traditional communal roundhouse)' marked with -ze means 'an object Y being like/as a maloca, having the size of a maloca'. ${ }^{16}$ Examples are given in (64-65):

\begin{tabular}{|c|c|c|c|}
\hline $\begin{array}{l}\text { ua } \\
\text { really }\end{array}$ & $\begin{array}{l}\text { nokae-ze } \\
\text { canoe-SIMIL.EQUAL.SIZE }\end{array}$ & $\begin{array}{l}\text { bai-re-d-e } \mathrm{e}_{\text {PRED }} \\
\text { find.be.visible-ATT-LK-3 }\end{array}$ & $\begin{array}{l}\text { kue-mona } \\
1 \text { sp:PE-ABL }\end{array}$ \\
\hline
\end{tabular}

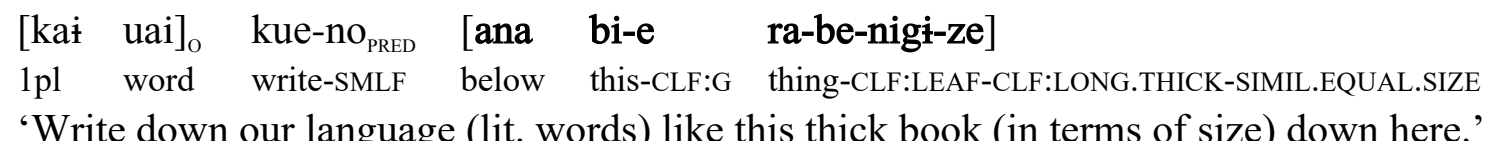

The Murui similative 'equal size' marker occurs with all types of nouns, regardless of their animacy. For instance, Katarina-ze refers to an object size in terms of the size of Katarina (whether big, small, etc.). The similative cannot be followed by nominal morphology, such as case or number. It can, however, head intransitive predicates. In (66), a speaker was comparing the size of a tree with the size of a house.

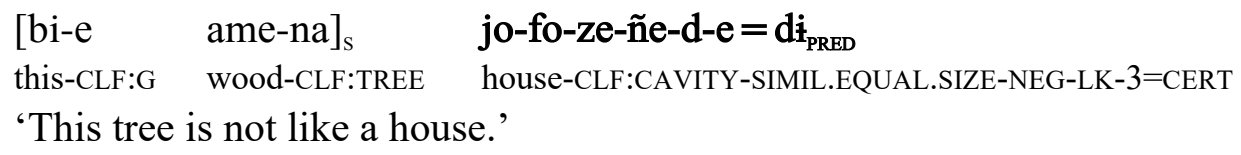

Elsewhere in the grammar, the readings of -ze are clearly similative, and do not involve 'equal size' meanings. This is the case with demonstratives, such as in bai-e-ze (that-CLF:G-SIMIL) 'like that', aki-e-ze (AUDIT-CLF:G-SIMIL) 'like that (as heard)', the question word ni-e-ze (Q2-CLF:GSIMIL) 'how', and the connective ie-ze (CONN-SIMIL) 'like that'. Additionally, two independent manner adverbs - raize 'well, correctly', as in (67), and feekuize 'slowly' - contain the formative $-z e$. Examples are given in (67-69):

\footnotetext{
${ }^{16}$ Murui similative marker is comparable to the similative in the Cariban languages. In Trio (a Cariban group the Witotoan people were in contact with), the similative -me has adverbial functions; it is a 'depictive' marker, and a marker of 'secondary predication'. It also has grammaticalised aspectual meanings (Carlin, 2007:328).
} 
(67)

raize nai-no! $!_{\text {PRED }}$

well.SIMIL speak-IMP

'Speak well!'

$\begin{array}{ll}\text { ní-e-ze } & \text { i-ti-o } ?_{\text {PRED }} \\ \text { Q2-CLF:G-SIMIL } & \text { exist-LK-2sg }\end{array}$

'How are you (lit. how do you exist)?'
mare mei kai
bi-e-ze
i-ya $\mathrm{PRED}_{\mathrm{PRE}}$
good.ATT so $1 \mathrm{p}$
this-CLF:G-SIMIL
exist-EVENT.NMLZ
'(It's) good to live like that.' (not in terms of size, but the way of life)

One exception is the demonstrative die- 'that'. Die- is unusual in that it is obligatorily marked with -ze relating to 'equal size'. As such, dieze can be interpreted as 'that much', and when used, it is always accompanied by a gesture indicating size. In (70), dieze refers to the size of the store:
[bai-mie ra-niai]
[tieda die-ze $]_{\text {PERF }}$
joone $!_{\text {PRED }}$
that-CLF:PR.M thing-COLL
store.Sp THAT.CLF:G-SIMIL.EQUAL.SIZE
put.TH.IMP

'Pile up his things like a store (size of things that are usually piled up in stores).'

The similative -ze might possibly be related to the postposition izoi 'similar' (§5.1). Among Murui speaker, there is a certain interchangeability of the expressions in (71a-b). Both are interpreted as 'this is the story', and are customarily used to end narrations.
a. aki-e-ze i-t-e
AUDIT-CLF:G-SIMIL exist-LK-3
b. aki-e izoi i-t-e
AUDIT-CLF:G similar exist-LK-3

\section{Summary}

This paper focused on comparative construction in Murui, a Witotoan language spoken in Northwest Amazonia. All Murui comparative constructions are similar in structure: they involve an overtly expressed standard marker which contains the locative -mo. The meanings of the standard marker refer to distance, interiority, and vertical position, and distinguish between superiority and inferiority. None of the structural elements of Murui comparative constructions have 'special' forms; all constituents have additional roles in the grammar. Murui has no dedicated superlative. Superlative readings are contextual, and are achieved by employing adjectives, nouns, and verbs preceded by the intensifier $e o$ 'very', and modifying nouns to indicate a set of referents. Expressing equality involves izoi- '(be) similar'. The notion of 'Y like/as X in terms of object's size' is expressed with the similative -ze on nouns and on the demonstrative die- 'that'; elsewhere, the similative $-z e$ has no 'equal size' readings. 


\section{References}

Aikhenvald, Alexandra Y. 2003. Classifiers: A Typology of Noun Categorization Devices. New York: Oxford University Press.

Aikhenvald, Alexandra Y. 2012. The Languages of the Amazon. New York: Oxford University Press.

Aikhenvald Alexandra Y. This volume. Comparison, contrast and similarity in Yalaku.

Aschmann, R. P. 1993. Proto Witotoan. Arlington: SIL \& the University of Texas.

Carlin, E. B. 2007. The borrowing of Cariban functional categories into Mawayana (Arawak). In A. Y. Aikhenvald and R. M. W. Dixon (eds.), Grammars in Contact: A Cross-linguistic Typology (Vol. 4), pp. 313-332. Oxford University Press: Oxford, UK.

Dixon, R. M. W. 2010a. Basic Linguistic Theory. Volume 1. Methodology. Oxford: Oxford University Press.

Dixon, R. M. W. 2010b. Basic Linguistic Theory. Volume 2. Grammatical Topics. Oxford: Oxford University Press.

Dixon, R. M. W. 2012. Basic Linguistic Theory. Volume 3. Further Grammatical Topics. Oxford: Oxford University Press.

Echeverri, Juan Alvaro. 1997. The People of the Center of the World. A Study in Culture, History and Orality in the Colombian Amazon. PhD dissertation. New York: New School for Social Research.

Echeverri, Juan Alvaro, Doris Fagua, and Katarzyna I. Wojtylak. Forthcoming. The Witotoan language family. In P. Epps and L. Michael (eds.), International Handbook of Amazonian Languages. Berlin: Mouton de Gruyter.

Fabre, Alain. 2005 (updated 2016). Diccionario etnolingüistico y guía bibliográfica de los pueblos indigenas sudamericanos: Witoto-Bora. Available at http://www.ling.fi/Entradas\%20diccionario/Dic=WitotoBora.pdf

Hardenburg, W. E. 1912. The Putumayo: The Devil's Paradise. Travels in the Peruvian Amazon Region and an Account of the Atrocities Committed upon the Indians therein. London: T. Fisher Unwin.

OIMA. 2008. Plan de vida del Pueblo Murui: Jurisdicción Organización Indígena Murui del Amazonas (OIMA). Colombia: Union Europea, Fundación ZIO-A'I, CISP.

Pineda Camacho, Roberto. 2000. Holocausto en el Amazonas: una historia social de la Casa Arana. Santafé de Bogotá: Planeta Colombiana Editorial.

Petersen de Piñeros, Gabriele. 2007. Nominal classification in Uitoto. International Journal of American Linguistics, 73, 389-409.

Ramirez, H. (1997). A Fala Tukano dos Ye'pa-Masa (Vol. 1). Manaus: Inspetoria Salesiana Missionária da Amazônia CEDEM.

Seifart, Frank. 2007. The prehistory of nominal classification in Witotoan languages. International Journal of American Linguistics, 73(4), 411-445.

Seifart, Frank and Payne, Doris L. 2007. Nominal classification in the North West Amazon: Issues in areal diffusion and typological characterization. International Journal of American Linguistics, 74(4), 381-387.

Smith-Stark, T. C. 1974. The plurality split. Papers from the Annual Regional Meeting of the Chicago Linguistic Society, 10, 657-671.

Vuillermet, Marine. This volume. Comparative, similative and simulative expressions in Ese Ejja.

Wojtylak, Katarzyna I. 2016. Classifiers as derivational markers in Murui (Northwest Amazonia). In Pavol Štekauer, Lívia Körtvélyessy and Salvador Valera (eds.), Word-Formation Across Languages, pp. 393-425. Newcastle- upon- Tyne: Cambridge Scholars Publishing.

Wojtylak, Katarzyna I. 2017. A Reference Grammar of Murui (Bue), a Witotoan Language of Northwest Amazonia. PhD dissertation. Cairns: James Cook University.

Wojtylak, Katarzyna I. 2018. The form and function of nominalizations in Murui (Witotoan). STUF Sprachtypologie und Universalienforschung, 71(1), 19-45 (Special issue Nominalization: A view from North West Amazonia, edited by S. E. Overall and K. I. Wojtylak).

Wojtylak, Katarzyna I. Forthcoming. Grammaticalization of body part terms in Murui, a Witotoan language of Northwest Amazonia. In Iwona Kraksa-Szlenk (ed.). Amsterdam, Philadelphia: John Benjamins. 